\title{
Interleukin-28B Polymorphism is a Pharmacogenetic Predictor during Sofosbuvir Plus Pegylated Interferon and Ribavirin Therapy for Chronic Hepatitis C Egyptian Patients
}

Hosni Dh Abd EL-Raheem ${ }^{1^{*}}$, Medhat H Hashem ${ }^{2}$, Alaa A Hemeida ${ }^{2}$, Mohamed E Ebeed ${ }^{2}$, Usama A Arafa ${ }^{3}$ and Laila M Yousef ${ }^{4}$

${ }^{1}$ Department of Medical Investigations, Sohag General Hospital, Sohag, Egypt

${ }^{2}$ Genetic Engineering and Biotechnology Research Institute (GEBRI), University of Sadat City, Menoufia, Egypt

${ }^{3}$ Department of Internal Medicine, Faculty of Medicine, Sohag University, Sohag, Egypt

${ }^{4}$ Department of Clinical Pathology, Faculty of Medicine, Sohag University, Sohag, Egypt.

\begin{abstract}
Background and aim: Interleukin-28B (IL-28B) polymorphism is a predictor of sustained virologic response (SVR), spontaneous clearance and personalizing therapy of hepatitis $\mathrm{C}$ virus (HCV). This study aimed to determine IL28B rs 12979860 polymorphism among chronic hepatitis C (CHC) Egyptian patients as a step in personalized HCV therapy and pharmacogenomics.

Methods: CHC Egyptian patients were received sofosbuvir (SOF) plus pegylated interferon (PEG-IFN) and ribavirin (RBV) for 12 weeks. A total of $82 \mathrm{HCV}$ infected Egyptian patients and 27 healthy individuals were included in the present study. CHC Patients were classified as achieving SVR if plasma HCV-RNA was undetectable (group A) and non-responders if plasma HCV-RNA was detectable (group B). IL28B genotypes were analyzed and their associations with SVR were selected.

Results: The end of treatment response (ETR) rate was 100\%. However, SVR12 was $76.8 \%$ (group A) and $23.2 \%$ relapsed (group B). Among studied CHC patients, 50\% were IL-28B TT, $40.2 \%$ CT, and 9.8\% CC. while the percentage of their frequencies in the healthy people were $18.5 \%, 51.8 \%$, and $29.6 \%$, respectively. These results showed that the frequencies of TT genotypes were more prevalent in HCV patients. The genotype $\mathrm{CC}(\mathrm{n}=8)$ achieved higher rates of SVR in group A (87.5\%) than relapsed patients in group B $(12.5 \%)$ and it had the least prevalence in group B compared with the frequencies of CT $(21.2 \%)$ and TT $(26.9 \%)$ genotypes. These results showed that CC genotype was associated with SVR.

Conclusions: It can be concluded that the individuals with IL28B TT genotype are more susceptible to HCV infection in Egyptian patients and relapse. Moreover, IL-28B CC is useful for pretreatment prediction of the outcome of HCV treatment. Hence, IL28B polymorphism could be considered as a pharmacogenetic predictor in personalized HCV therapy and pharmacogenomics during SOF plus PEG-IFN and RBV therapy for CHC Egyptian patients.
\end{abstract}

Keywords: Chronic hepatitis C; Sofosbuvir; Pegylated interferon; Ribavirin; Interleukin 28B; Personalizing therapy

\section{Introduction}

In the late 1980 s, HCV was discovered as non-A, non-B hepatitis [1]. HCV is a small particle, enveloped and positive sense singlestranded ribonucleic acid (+ssRNA) [2,3]. It belongs to the Hepacivirus genus within the Flaviviridae family [4,5].

Globally, there are 130-150 million people chronically infected with HCV [6]. In Africa, the highest prevalence has been reported in Egypt and Cameroon $[7,8]$. Egypt has the highest prevalence rate of HCV in the world $[9,10]$.

HCV can lead to chronic hepatitis disease in millions of people and are the most common cause of liver cirrhosis and hepatocellular carcinoma [11]. Seven HCV genotypes and sixty seven subtypes have been identified [12]. HCV genotype 4 (HCV-G4) is the most common infection in Egypt, approximately $90 \%$ of all HCV patients [13-15].

Recently, many antiviral drugs have been developed. SOF was given in combination with RBV and take with or without Peg-IFN [6]. Moreover, Lawitz et al. [16] revealed that SOF plus Peg-IFN and RBV for just 12 weeks can achieve $89 \%$ and $96 \%$ SVR in treatment of HCV-G1 and HCV-G4 patients, respectively.
Many host genetic factors play an important role in the spontaneous clearance of $\mathrm{HCV}$ and the response of antiviral treatment in $\mathrm{CHC}$ patients. Genome wide association studies (GWAS) have identified a SNP near the IL28B gene on chromosomes 19 that encodes IFN- $\lambda 3$ $[17,18]$. The SNP rs 12979860 is located $3 \mathrm{~kb}$ upstream of the IL28B gene, which codes for IFN- $\lambda 3$ and strongly predicts response to $\mathrm{HCV}$ treatment $[19,20]$.

IL28B genotypes are strongly associated with treatment efficacy in patients infected with HCV-G1 and G4. Thus, IL28B genotyping is useful for pretreatment prediction of the outcome of direct acting antiviral (DAA) plus Peg-IFN/RBV therapy [21].

*Corresponding author: Hosni Dh Abd EL-Raheem, Department of Medical Investigations, Sohag General Hospital, Sohag, Egypt, Tel: 0201000398711; E-mail: hosnidhahi@gmail.com

Received January 11, 2017; Accepted February 10, 2017; Published February 21, 2017

Citation: Abd EL-Raheem HD, Hashem MH, Hemeida AA, Ebeed ME, Arafa UA et al. (2017) Interleukin-28B Polymorphism is a Pharmacogenetic Predictor during Sofosbuvir Plus Pegylated Interferon and Ribavirin Therapy for Chronic Hepatitis C Egyptian Patients. J Pharmacogenomics Pharmacoproteomics 8: 166. doi: 10.4172/2153-0645.1000166

Copyright: (c) 2017 Abd EL-Raheem HD, et al. This is an open-access article distributed under the terms of the Creative Commons Attribution License, which permits unrestricted use, distribution, and reproduction in any medium, provided the original author and source are credited. 
Citation: Abd EL-Raheem HD, Hashem MH, Hemeida AA, Ebeed ME, Arafa UA, et al. (2017) Interleukin-28B Polymorphism is a Pharmacogenetic Predictor during Sofosbuvir Plus Pegylated Interferon and Ribavirin Therapy for Chronic Hepatitis C Egyptian Patients. J Pharmacogenomics Pharmacoproteomics 8: 166. doi: 10.4172/2153-0645.1000166

HCV infections spontaneously clear in approximately $15-45 \%$ of infected individuals $[22,23]$. Currently, there is a strong association between the rate of spontaneous clearance of $\mathrm{HCV}$ and IFN- $\lambda$ polymorphisms [24]. Furthermore, killer cell immunoglobulin-like receptor (KIR) genes with IFN- $\lambda 3$ polymorphisms indirectly influence the activity of natural killer (NK) cells and can predict spontaneous resolution of acute HCV infection [25].

IL28B SNP polymorphism improves viral kinetics during PEGIFN/RBV therapy [26]. However, Abdelwahab et al. [27] demonstrated that SNP rs12979860 polymorphism does not affect viral load among CHC Egyptian patients.

The CC genotype of SNP rs12979860 is the strongest genetic pretreatment predictor of SVR in HCV-G1 and G4 patients $[21,28]$. Moreover, high expression of IFN- $\lambda$ has been recorded in patients with rs12979860 CC variant [29]. Recently, IL28B SNP, alpha fetoprotein level, and cytotoxic T-Lymphocytes antigen-4 (CTLA-4) SNP could be used in conjunction to predict treatment response in HCV-G4 infected Egyptian patients [30]. In addition, Esmail et al. [31] demonstrated that IL-28B SNP polymorphism is considered as a vital predictor of viral relapse.

$\mathrm{HCV}$ induces IFN- $\lambda$ and interferon stimulated genes (ISGs) expression [32]. ISGs repress HCV replication [33]. Additionally, Marcello et al. [34] emerged that IFN- $\lambda$ and IFN- $\alpha$ inhibit HCV replication. Hence, in the future, we can predict that pegylated recombinant interleukin 28 (PEG-rIL-28) may be used as a new antiviral drug in $\mathrm{HCV}$ treatment in combination with other antiviral agents.

Pharmacogenomics is the study of genetic variations that influence the response of individuals to drug treatment [35]. It can help in selection of the optimal drug, dose and avoid adverse drug reactions [36]. Clinically, many types of adverse drug reactions are related to polymorphic gene alleles [37].

Personalized medicine is a form of medicine that uses information about a person's genes, proteins, and environment to prevent, diagnose, and treat disease [38]. Besides, Pharmacogenomic information offers a personalized medicine approach to help clinicians and patients make better informed decisions to maximize response and minimize toxicity for the treatment of chronic HCV infection [39].

In Personalized medicine, molecular markers were used for detection of specific genetic traits for preventing and treating different pathologies [40]. In that way, Yanase et al. [41] demonstrated that some SNPs are associated with the metabolism of different drugs. IL28B genotyping was used in personalizing of HCV therapy as a pharmacogenetic predictor in $\mathrm{CHC}$ patients $[42,43]$.

The Personalized medicine is our way and chance to improve health care system. Hence, the aim of this study is to determine SNP rs12979860 molecular marker genotypes distribution among CHC Egyptian patients as a step in personalized HCV therapy and pharmacogenomics during SOF plus PEG-IFN and RBV therapy.

\section{Materials and Methods}

\section{Patients}

The present study included 82 Egyptian patients with CHC (68 men and 14 women), mean age $51.5 \pm 10.59$ years. All CHC patients were collected from Sohag center of cardiac and digestive system, Sohag, Egypt. Seventy four were treatment-naïve and eight previously treated patients with Peg-IFN/RBV therapy for 12 weeks and non-response. In addition, $25.6 \%$ of patients had cirrhosis. Anti-HCV antibodies (antiHCV Abs) were detected by using enzyme linked immunosorbent assay (ELISA) technique according to the manufacturer's instructions (spectrum diagnostics reagents, Egypt, $3^{\text {rd }}$ generation, cat. No. 1308001). All reactive anti-HCV Abs were confirmed by reverse transcriptionPCR (RT-PCR) for HCV.

\section{Control group}

The individuals of control group were consisted of 27 healthy individuals (19 males and 8 females), mean age $33 \pm 5.22$ years, and were selected from blood bank unit in Sohag general hospital, Sohag, Egypt. They were seronegative for anti-HCV Abs, hepatitis B surfaces antigen (HBs Ag), hepatitis B core total antibodies (anti-HBc total) and anti-bilharzias. No abnormal laboratory findings with normal liver ultrasound.

\section{Treatment regiments}

$\mathrm{CHC}$ patients were received 12 weeks of triple combination therapy with SOF (400 mg once daily), Peg-INF $(180 \mathrm{mcg} / 0.5 \mathrm{ml}$; fixed dose/ week) plus RBV (1000 mg for $\leq 75 \mathrm{Kg}$ or $1200 \mathrm{mg}$ for $>75 \mathrm{Kg}$ ).

\section{Blood sampling}

Two blood samples were obtained from each subject. The first sample was collected in serum-separating tubes. Blood was left at room temperature to clot, and then centrifuged at 4000-6000 rpm; serum was separated for biochemical analysis and RNA extraction. The second sample was collected in a clean and dry vacutainer tube with ethylene diamine tetra acetic acid (EDTA) anticoagulant for hematology analysis and IL28B SNP rs12979860 genotypes distribution study.

\section{HCV RNA extraction}

RNA was extracted from all serum samples $(140 \mu \mathrm{L})$ by using of the QIAamp viral RNA extraction kit (Qiagen, Cat. No. 52904) according to manufacturer's instructions. Briefly, samples were lysed and the RNA was captured on the spin columns provided. The RNA was washed, eluted and then stored at $-20^{\circ} \mathrm{C}$ until used in RT-PCR amplification.

\section{Reverse transcription-PCR procedure}

5 '-UTR of HCV was amplified by using one step RT-PCR kit (Qiagen, Cat. No. 210210). The QIAGEN one step RT-PCR kit is designed to be used with primer pair selected from the highly conserved 5 '-UTR of HCV genome [1]. The master mix typically contains all the components required for RT-PCR except the template RNA. The reactions were performed in $25 \mu \mathrm{l}$ total volume and consist of the master mix plus template RNA. The 5'-UTR of HCV RNA amplification was performed by using of the Gene Amp PCR system 2400 (Biometra) programmed for 35 cycles. PCR products were visualized on $1.0 \%$ agarose using UV-trans-illuminator and photographed by a digital camera (FUJI 100) with orange filter [44].

\section{DNA extraction}

DNA extraction was done by using G-spin" total DNA extraction kit according to manufacturer's instructions (Spain, Cat. No. 17045). In brief, samples were lysed and the DNA was captured on the spin columns provided. The DNA was washed, eluted and then stored at $-20^{\circ} \mathrm{C}$ until used in PCR amplification.

\section{IL28B SNP rs12979860 genotyping detection}

IL28B SNP rs12979860 genotyping was detected by multiplex tetra-primer PCR method (Control f: GCT CAG CGC CTC TTC CTC CT-3, Control R: TCC CAT ACA CCC GTT CCT GT-3, IL28B (T) F, 
Citation: Abd EL-Raheem HD, Hashem MH, Hemeida AA, Ebeed ME, Arafa UA, et al. (2017) Interleukin-28B Polymorphism is a Pharmacogenetic Predictor during Sofosbuvir Plus Pegylated Interferon and Ribavirin Therapy for Chronic Hepatitis C Egyptian Patients. J Pharmacogenomics Pharmacoproteomics 8: 166. doi: 10.4172/2153-0645.1000166

Page 3 of 5

AGG AGC TCC CCG AAG GAG T-3, IL28B (C) R: TGC AAT TCA ACC CTG GTA CG-3) [45]. The reactions were performed in $50 \mu \mathrm{l}$ total volume and consist of the master mix plus template DNA. The amplicons were separated by $2 \%$ agarose gel electrophoresis and stained with ethidium bromide $(0.5 \mathrm{mg} / \mathrm{L})$. Both homozygous (CC and TT) and heterozygous genotypes (CT) were detected on agarose gel.

\section{Statistical analysis}

Statistical analyses were performed by statistical package for social program (SPSS) software (version 20, SPSS, Inc, Chicago, IL, USA). The variables of $\mathrm{CHC}$ patients and the healthy individuals of control group were displayed as means \pm standard deviation (SD).

\section{Results}

As shown in Table 1 , the baseline characteristics of $\mathrm{CHC}$ patients $(n=82)$ and healthy individuals of control group $(n=27)$ were selected before therapy. All reactive anti-HCV Abs specimens were confirmed by direct detection of HCV RNA by RT-PCR (Figure 1).

\section{End treatment response}

All CHC Egyptian patients enrolled in this study were received 12 weeks of triple combination therapy. Followed by RT-PCR assay, HCV RNA is not detected in the blood specimens and the ETR rate was $100 \%$.

\section{Side effects during treatment period}

Some side effects occurred during treatment period including thrombocytopenia $\left(<150,000\right.$ cells $\left./ \mathrm{mm}^{3}\right)$, hemoglobin decreasing $(\leq 12.5 \mathrm{~g} / \mathrm{dl}$ for male and $\leq 11 \mathrm{~g} / \mathrm{dl}$ for female), leucopenia ( $<4,000$ cells/ $\mathrm{mm}^{3}$ ), and ALT elevation in group A and B, as shown in Table 2, these side effects were increased and observed in relapsed patients than SVR individuals.

\section{Sustained virologic response}

After 12 weeks from termination of the triple combination therapy, all enrolled CHC Egyptian patients were observed by RT-PCR assay. Patients were classified as achieving SVR if plasma HCV-RNA was undetectable and non-responders if plasma HCV-RNA was detectable. Overall, sixty three patients $(76.8 \%)$ were SVR12 to the treatment (group A) but nineteen patients (23.2\%) were relapsed (group B). Furthermore, rates of SVR12 among previously treated and treatmentnaïve patients were $87.5 \%$ and $75.7 \%$, respectively (Figure 2 ).

\section{IL28B SNP rs12989760 polymorphism}

The SNP rs12979860 genotypes and their distributions were selected

\begin{tabular}{|c|c|c|}
\hline Variables & Control group $(\mathbf{n}=\mathbf{2 7})$ & CHC $(\mathbf{n = 8 2})$ \\
\hline Age $($ year $)$ & $33 \pm 5.22$ & $51.5 \pm 10.59$ \\
\hline Gender $(\mathrm{M} / \mathrm{F})$ & $19 / 8$ & $68 / 14$ \\
\hline Hb & $14.31 \pm 0.59$ & $13.29 \pm 1.08$ \\
\hline WBC $\left(\times 10^{3} / \mu \mathrm{l}\right)$ & $7.84 \pm 1.58$ & $6.88 \pm 2.10$ \\
\hline Platelets $\left(\times 10^{3} / \mu \mathrm{l}\right)$ & $227 \pm 30$ & $190 \pm 35$ \\
\hline AST (U/L) & $31.5 \pm 7.9$ & $47.5 \pm 17.9$ \\
\hline ALT (U/L) & $28.9 \pm 10.3$ & $46.3 \pm 22.4$ \\
\hline Alb $(\mathbf{m g} / \mathrm{dl})$ & $4.23 \pm 0.15$ & $3.86 \pm 0.25$ \\
\hline Creatinine $(\mathbf{m g} / \mathrm{dl})$ & $0.87 \pm 0.10$ & $0.95 \pm 0.13$ \\
\hline Cirrhosis & $0(0 \%)$ & $21(25.6 \%)$ \\
\hline
\end{tabular}

M: Male; F: Female; Hb: Hemoglobin; WBC: White Blood Cells; AST: Aspartate Aminotransferase; ALT: Alanine Aminotransferase; Alb: Albumin

Table 1: Characteristics of the studied HCV patients and healthy controls. in CHC patients and healthy people of control group (Figures $3 \mathrm{a}$ and 3b). The frequencies of CC, CT and TT genotypes were 9.8\%, 40.2\%, and $50 \%$ respectively in $\mathrm{CHC}$ patients, but for healthy control group, the frequencies were $29.6 \%, 51.8 \%$ and $18.5 \%$ for CC, CT, and TT respectively (Table 3). These results showed that the frequencies of TT variants were more prevalent in CHC patients compared with healthy individuals group.

\section{IL28B variants and SVR}

Among $82 \mathrm{CHC}$ patients treated with triple combination therapy, 19 patients did not achieve a SVR12 while 63 patients achieved a SVR12. The relation between SVR of HCV and IL28B rs12989760 genotypes distribution was analyzed (Table 4). The genotype CC was achieved higher rates of SVR12 in group A (87.5\%) than group B (12.5\%), moreover it had a low prevalence in relapsed patients compared with the frequencies of CT and TT genotypes (21.2\% and $26.9 \%$ respectively). These results emerged that CC genotypes were associated with SVR and influence the SVR rate in patients with CHC treated with triple therapy.

\section{Discussion}

As a result of GWAS, a SNP near the IL28B gene on chromosome 19 that encodes IFN- $\lambda 3$ have been identified [17,18]. IFN- $\lambda 3$ polymorphisms were associated with viral resolution and treatment outcomes among CHC patients $[19,46]$.

Recently, pharmacogenomic is related to drug response and precision medicine [39]. Precision medicine allows doctors and researchers to predict treatment strategies for health care improvement. Moreover, IL28B genotyping was used as a pharmacogenetic predictor in personalizing of HCV therapy $[42,43]$.

In the present study, IL-28B polymorphism among CHC Egyptian patients and healthy individuals were determined as a step in

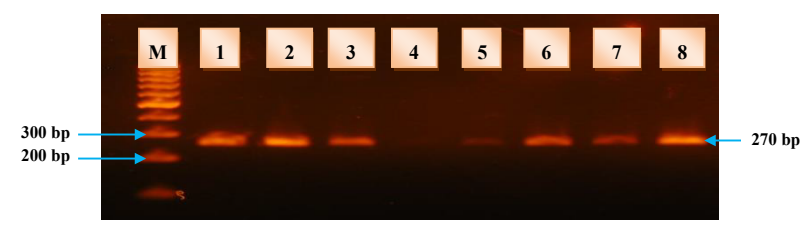

Figure 1: Ethidium bromide stained agarose gel electrophoresis of HCV 5'-UTR amplification by RT-PCR, M: 100 bp DNA ladder, lane 4: negative control, lane 7: positive control and Lanes 1, 2, 3, 5, 6 \& 8: PCR-positive results (bands sizing $270 \mathrm{bp}$ in each).

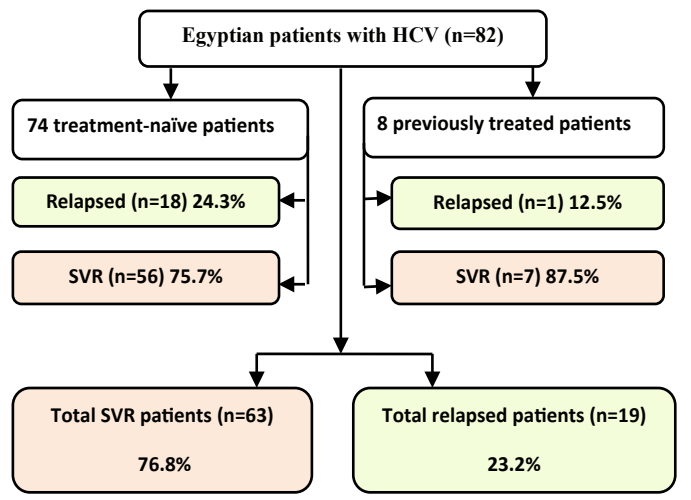

Figure 2: SVR flowchart in $\mathrm{CHC}$ patients $(n=82)$. 
Citation: Abd EL-Raheem HD, Hashem MH, Hemeida AA, Ebeed ME, Arafa UA, et al. (2017) Interleukin-28B Polymorphism is a Pharmacogenetic Predictor during Sofosbuvir Plus Pegylated Interferon and Ribavirin Therapy for Chronic Hepatitis C Egyptian Patients. J Pharmacogenomics Pharmacoproteomics 8: 166. doi: 10.4172/2153-0645.1000166

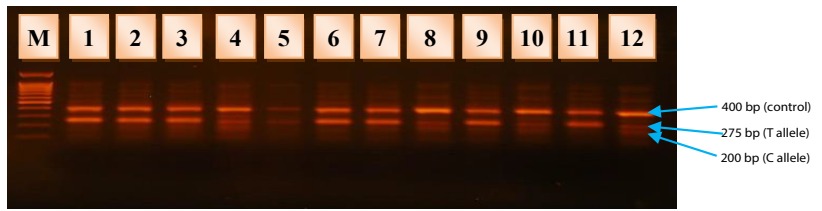

Figure 3a: Ethidium bromide stained agarose gel electrophoresis of SNP rs12979860 amplification by PCR, M: 100 bp DNA ladder, lane 1, 2, 3, 5, 6 , 7,9 and 11 the electrophoresis pattern of genotypes TT, Lanes 4, 8, 10 and 12 genotypes CT.

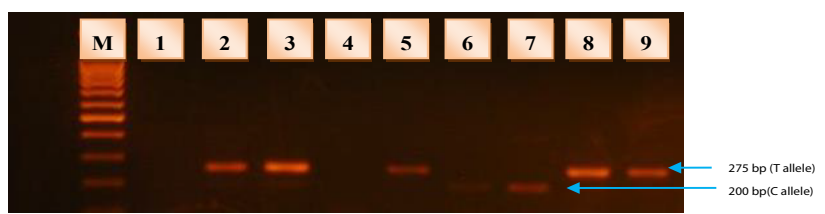

Figure 3b: PCR analysis of IL28B SNP rs12979860 (without control primers) and the products of PCR were separated by $2 \%$ agarose gel electrophoresis and stained with ethidium bromide $(0.5 \mathrm{mg} / \mathrm{L})$. M: $100 \mathrm{bp}$ DNA ladder, lane 1 and 4: negative control, lanes $2,3,5,8$, and 9 the electrophoresis pattern of genotypes TT, Lanes 6 and 7 genotypes CC.

\begin{tabular}{|c|c|c|}
\hline Side effect & Group A (n=63) & Group B (n=19) \\
\hline Leucopenia & $26.9 \%(n=17)$ & $52.6 \%(n=10)$ \\
\hline Hb decreasing & $66.6 \%(n=42)$ & $73.6 \%(n=14)$ \\
\hline Thrombocytopenia & $28.5 \%(n=18)$ & $42.1 \%(n=8)$ \\
\hline ALT elevation & $26.9 \%(n=17)$ & $31.5 \%(n=6)$ \\
\hline
\end{tabular}

Table 2: Hematologic abnormalities and ALT elevation.

\begin{tabular}{|c|c|c|}
\hline Genotypes & Control group (n=27) & CHC (n=82) \\
\hline CC & $8(29.6 \%)$ & $8(9.8 \%)$ \\
\hline CT & $14(51.8 \%)$ & $33(40.2 \%)$ \\
\hline TT & $5(18.5 \%)$ & $41(50 \%)$ \\
\hline C allele (total) & $30(55.6 \%)$ & $49(29.9 \%)$ \\
\hline T allele (total) & $24(44.4 \%)$ & $115(70.1 \%)$ \\
\hline
\end{tabular}

Table 3: IL28B rs12989760 polymorphism among whole studied groups.

\begin{tabular}{|c|c|c|}
\hline CHC Patients & Group A (SVR) & Group B (Relapsed) \\
\hline CC $(n=8)$ & $7(87.5 \%)$ & $1(12.5 \%)$ \\
\hline CT $(n=33)$ & $26(78.8 \%)$ & $7(21.2 \%)$ \\
\hline TT $(n=41)$ & $30(73.2 \%)$ & $11(26.9 \%)$ \\
\hline
\end{tabular}

Table 4: IL28B rs12989760 polymorphism and SVR in CHC patients.

personalized HCV therapy and pharmacogenomics during SOF plus PEG-IFN and RBV therapy to give a right drug to the right patient and improve health care system.

SOF plus Peg-IFN and RBV for just 12 weeks leads to $89 \%$ and 96\% SVR in treatment of HCV-G1 and HCV-G4 patients, respectively [16]. In our study all CHC Egyptian patients were treated with triple combination therapy and were followed by RT-PCR assay, HCV RNA is not detected in the blood specimens and the ETR rate was $100 \%$. However, after 12 weeks from termination of the therapy, RT-PCR was observed, sixty three patients $(76.8 \%)$ were SVR12 to the treatment (group A) but nineteen patients (23.2\%) were relapsed (group B). Furthermore, rates of SVR among previously treated and treatmentnaïve patients were $87.5 \%$ and $75.7 \%$, respectively. Hence, SOF plus Peg-IFN and RBV for 12 weeks is effective in previously treated than treatment-naïve patients.

In the current study, some side effects occurred during treatment period in some cases, including thrombocytopenia, hemoglobin decreasing, leucopenia, and ALT elevation. In particular, these side effects were increased and observed in relapsed patients than SVR individuals. In that way, it was postulated by Torriani et al. [47] that RBV causes a hemolytic anemia and interferon can suppress bone marrow production of red blood cells, platelets and leukocytes. Additionally, ALT is the most specific marker of liver function and is used as an indirect marker of liver inflammation or injury [48].

The Prevalence of SNP rs12979860 genotypes CC, CT and TT genotypes in HCV patients and healthy persons were detected and the results showed that the frequency of TT genotype represents the highest widespread in CHC patients and the least prevalence in the healthy individuals. Hence, the TT genotype may be more effective in the progression of $\mathrm{HCV}$ infection and may increase the risk of HCC $[49,50]$

The relation between SVR of HCV and IL28B SNP rs12989760 polymorphisms were studied. The genotype CC achieved the highest rate of SVR12 compared with CT and TT genotypes. Moreover, CC genotype had the least prevalence in the relapsed patients compared with the frequencies of $\mathrm{CT}$ and TT variants. These results indicated that CC genotype was associated with SVR. In that way, Zeuzem et al. [51] recorded that the CC variant of rs12979860 was associated with increased likelihood of achieving SVR in comparison with nonCC variants. Consequently, the CC variant of SNP rs12979860 is the strongest genetic pretreatment predictor of SVR in HCV-G1 and G4 patients $[21,28]$

\section{Conclusion}

In sum, IL-28B CC is the predictive factor of response to treatment with SOF plus Peg-IFN and RBV combination therapy, and the individuals with IL28B TT genotype are more susceptible to HCV infection in Egyptian patients and relapse. In addition, this study provides that IL28B polymorphism could be considered as a pharmacogenetic predictor in personalized HCV therapy and pharmacogenomics during SOF plus PEG-IFN and RBV therapy for CHC Egyptian patients.

\section{References}

1. Choo QL, Kuo G, Weiner AJ, Overby LR, Bradley DW, et al. (1989) Isolation of a cDNA clone derived from a blood-borne non-A, non-B viral hepatitis ge-nome. Science 244: 359-362.

2. Vieyres G, Dubuisson J, Pietschmann T (2014) Incorporation of hepatitis C virus $\mathrm{E} 1$ and $\mathrm{E} 2$ glycoprotein: the keystones on a peculiar virion. Viruses 6 : 1149-1187.

3. Wang H, Tai AW (2016) Mechanisms of Cellular Membrane Reorganization to Sup-port Hepatitis C Virus Replication. Viruses 8.

4. Barth H, Liang TJ, Baumert TF (2006) Hepatitis C virus entry: molecular biology and clinical implications. Hepatology 44: 527-535.

5. Pybus OG, Thézé $J(2016)$ Hepacivirus cross-species transmission and the origins of the hepatitis $C$ virus. Curr Opin Virol 16: 1-7.

6. http://www.who.int/mediacentre/factsheets/fs164/en/

7. Nerrienet E, Pouillot R, Lachenal G, Njouom R, Mfoupouendoun J, et al. (2005) Hepatitis C virus infection in cameroon: A cohort-effect. J Med Virol 76: 208-214.

8. Guerra J, Garenne M, Mohamed MK, Fontanet A (2012) HCV burden of infection in Egypt: results from a nationwide survey. J Viral Hepat 19: 560-567.

9. Esmat G (2013) Hepatitis C in the Eastern Mediterranean Region. East Mediterr Health J 19: 587-588.

10. El-Guendy NM, Helwa R, El-Halawany MS, Abdel Rahman Ali S, Tantawy Aly M (2016) The Liver MicroRNA Expression Profiles Associated With Chronic Hepatitis C Virus (HCV) Genotype-4 Infection: A Preliminary Study. Hepat Mon 16: e33881. 
Citation: Abd EL-Raheem HD, Hashem MH, Hemeida AA, Ebeed ME, Arafa UA, et al. (2017) Interleukin-28B Polymorphism is a Pharmacogenetic Predictor during Sofosbuvir Plus Pegylated Interferon and Ribavirin Therapy for Chronic Hepatitis C Egyptian Patients. J Pharmacogenomics Pharmacoproteomics 8: 166. doi: 10.4172/2153-0645.1000166

11. Canavese M, Wijesundara D, Maddern GJ, Grubor-Bauk B, Hauben E (2016) Hepatitis $C$ virus drives the pathogenesis of hepatocellular carcinoma: from immune evasion to carcinogenesis. Clin Transl Immunol 5: e101.

12. Smith DB, Bukh J, Kuiken C, Muerhoff AS, Rice CM (2014) Expanded classification of hepatitis $C$ virus into 7 genotypes and 67 subtypes: updated criteria and genotype assignment web resource. Hepatology 59: 318-327.

13. Abdel-Hamid M, El-Daly M, Molnegren V, El-Kafrawy S, Abdel-Latif S, et al (2007) Genetic diversity in hepatitis C virus in Egypt and possible association with hepatocellular carcinoma. J Gen Virol 88: 1526-1531.

14. Taha AA, El-Ray A, El-Ghannam M, Mounir B (2010) Efficacy and safety of a novel pegylated interferon alpha-2a in Egyptian patients with genotype 4 chronic hepatitis C. Can J Gastroenterol 24: 597-602.

15. Doss W, Shiha G, Hassany M, Soliman R, Fouad R , et al. (2015) Sofosbuvir plus ribavirin for treating Egyptian patients with hepatitis $C$ genotype 4 . J Hepatol 63: 581-585

16. Lawitz E, Mangia A, Wyles D, Rodriguez-Torres M, Hassanein T, et al. (2013) Sofosbuvir for previously untreated chronic hepatitis $C$ infection. N Engl J Med 368: 1878-1887.

17. Martínez-Gómez LE, Chávez-Tapia NC, Burguete-García Al, Aguilar-Olivos $\mathrm{N}$, Madrid-Marina V, et al. (2012) IL28B polymorphisms predict the response to chronic hepatitis $C$ virus infection treatment in a Mexican population. Ann Hepatol 11: 876-881.

18. Stättermayer AF, Ferenci P (2015) Effect of IL28B genotype on hepatitis B and $C$ virus infection. Curr Opin Virol 14: 50-55.

19. Ge D, Fellay J, Thompson AJ, Simon JS, Shianna KV, et al. (2009) Genetic variation in IL28B predicts hepatitis C treatment-induced viral clear-ance. Nature 461: 399-401.

20. Fateh A, Aghasadeghi MR, Keyvani H, Mollaie HR, Yari S, et al. (2015) High resolution melting curve assay for detecting rs 12979860 IL28B polymorphisms involved in response of Iranian patients to chronic hepatitis $C$ treatment. Asian Pac J Cancer Prev 16: 1873-1880.

21. Matsuura K, Watanabe T, Tanaka Y (2014) Role of IL28B for chronic hepatitis C treatment toward personalized medicine. J Gastroenterol Hepatol 29 241-249.

22. Kong F, Pan Y, Chi X, Wang X, Chen L, et al. (2014) Factors associated with spontaneous clearance of Hepatitis $C$ vi-rus in Chinese population. Biomed Res Int 2014: 527030.

23. Le Marchand C, Bahia F, Page K, Brites C (2015) Hepatitis C virus infection and spontaneous clearance in HTLV-1 and HIV co-infected patients in Salvador, Bahia, Brazil. Braz J Infect Dis 19: 486-491.

24. Heim MH, Bochud PY, George J (2016) Host-hepatitis C viral interactions: The role of genetics. J Hepatol 65: S22-S32.

25. Depla M, Pelletier S, Bédard N, Brunaud C, Bruneau J, et al. (2016) IFN- $\lambda 3$ polymorphism indirectly influences NK cell phenotype and function during acute HCV infection. Immun Inflamm Dis 4: 376-388.

26. Thompson AJ, Muir AJ, Sulkowski MS, Ge D, Fellay J, et al. (2010) Interleukin28B polymorphism improves viral kinetics and is the strongest pretreatment predictor of sustained virologic response in genotype 1 hepatitis $C$ virus. Gastroenterology 139: 120-129.

27. Abdelwahab SF, Zakaria Z, Allam WR, Hamdy S, Mahmoud MA, et al. (2015) Interleukin 28B.rs12979860 genotype does not affect hepatitis $C$ viral load in Egyptians with genotype 4 infection. Arch Virol 160: 2833-2837.

28. Abdelwahab SF, Zakaria Z, Allam WR, Hamdy S, Mahmoud MA, et al. (2015) Interleukin 28B Polymorphism Predicts Treatment Outcome Among Egyptian Patients Infected With HCV Genotype 4. Hepatogastroenterology 62: 947-950.

29. Lalle E, Bordi L, Caglioti C, Garbuglia AR, Castilletti C, et al. (2014) IFNAlpha receptor-1 upregulation in PBMC from HCV naïve patients carrying CC genotype. Possible role of IFN-lambda. PLoS One 9: e93434.

30. Rizk HH, Hamdy NM, Al-Ansari NL, El-Mesallamy HO (2016) Pretreatment predictors of response to PegIFN-RBV therapy in Egyptian Patients with HCV Genotype 4. PLoS One 11: e0153895

31. Esmail MA, Hassuna NA, Amr KS, Ghazawy ER, Abdel-Hamid M (2016) Polymorphisms at IL28B gene as predictors of viral relapse in genotype 4 Egyptian hepatitis C patients. J Med Virol 88: 481-486.

32. Marukian S, Andrus L, Sheahan TP, Jones CT, Charles ED, et al. (2011)
Hepatitis $C$ virus induces interferon- $\lambda$ and interferon-stimulated genes in primary liver cultures. Hepatology 54: 1913-1923.

33. Metz P, Reuter A, Bender S, Bartenschlager R (2013) Interferon-stimulated genes and their role in controlling hepatitis $\mathrm{C}$ virus. J Hepatol 59: 1331-1341.

34. Marcello T, Grakoui A, Barba-Spaeth G, Machlin ES, Kotenko SV, et al. (2006) Interferons alpha and lambda inhibit hepatitis $C$ virus replication with distinct signal transduction and gene regulation kinet-ics. Gastroenterology 131: 1887-1898.

35. Wang L, McLeod HL, Weinshilboum RM (2011) Genomics and drug response. N Engl J Med 364: 1144-1153.

36. Amstutz U, Carleton BC (2011) Pharmacogenetic testing, time for clinical practice guidelines. Clin Pharmacol Ther 89: 924-927.

37. Cann HM, de Toma C, Cazes L, Legrand MF, Morel V, et al. (2002) A human genome diversity cell line panel. Science 296 : 261-262.

38. Montserrat E, Bauman T, Delgado J (2016) Present and future of personal-ized medicine in CLL. Best Pract Res Clin Haematol 29: 100-110.

39. Kawaguchi-Suzuki M, Frye RF (2014) The role of pharmacogenomics in the treatment of chronic hepatitis C infection. Pharmacotherapy 34: 185-201.

40. Pinho JR, Sitnik R, Mangueira CL (2014) Personalized medicine and the clinical laboratory. Einstein (Sao Paulo) 12: 366-373.

41. Yanase K, Tsukahara S, Mitsuhashi J, Sugimoto Y (2006) Functional SNPs of the breast cancer resistance protein-therapeutic effects and inhibito development. Cancer Lett 234: 73-80.

42. Booth DR, Ahlenstiel G, George J (2012) pharmacogenomics of hepatitis C infections: personalizing therapy. Genome Med 4: 99.

43. Cariani E, Roli L, Missale G, Villa E, Ferrari C, et al. (2016) Interleuin 28B polymorphisms as predictors of sustained virological response in chronic hepatitis C: systemaic review and meta analysis: Pharmacogenomics $\mathrm{J} 16$ : 18-29.

44. Hemeida AA, Osman M, El-shahat M, Hashem MH, Mahmoud A, et al. (2011) Genetic Variations in a Conserved 5'-untranslated Region of Hepatitis C Virus Isolated from Egypt. Int J Virol 91: 99.

45. Jeong SH, Jung YK, Yang JW, Park SJ, Kim JW, et al. (2012) Efficacy of peginterferon and ribavirin is associated with the IL28B gene in Korean patients with chronic hepatitis C. Clin Mol Hepatol 18: 360-367.

46. Zhang R, Shao C, Huo N, Li M, Xu X (2016) Association of IL28B Genotypes and Baseline Serum Interferon- $y$-Inducible-Protein-10 Levels with Treatment Re-sponse in Hepatitis C Virus Patients in China. Gut Liver 10: 446-455.

47. Torriani FJ, Rodriguez-Torres M, Rockstroh JK, Lissen E, Gonzalez-García J et al. (2004) Peginterferon Alfa-2a plus ribavirin for chronic hepatitis C virus infection in HIV-infected patients. N Engl J Med 351: 438-450

48. Lee DH, Silventoinen K, Jacobs DR Jr, Jousilahti P, Tuomileto J (2004) gamma-Glutamyltransferase, obesity, and the risk of type 2 diabetes: observational cohort study among 20,158 middle-aged men and women. J Clin Endocrinol Metab 89: 5410-5414.

49. Taheri S, Aygen B, Korkmaz K, Yıldız O, Zararsız G, et al. (2015) Characterization of the Interleukin-28B Gene rs12979860 C/T Polymorphism in Turkish Chronic Hepatitis C Patients and Healthy Individuals. Balkan Med J 32: 147-155.

50. Zhang Y, Zhu SL, Chen J, Li LQ (2016) Meta-analysis of associations of interleukin28B polymorphisms rs8099917 and rs12979860 with development of hepatitis virus-related hepatocellular carcinoma. Onco Targets Ther 9: 3249-3257.

51. Zeuzem S, Soriano V, Asselah T, Bronowicki JP, Lohse AW, et al. (2013) Faldaprevir and deleobuvir for CV genotype 1 infection. N Engl J Med 369: 630-639. 